\title{
Alliances in Financial Ecosystems: A Source of Organizational Legitimacy for Fintech Startups and Incumbents
}

\author{
Christopher Svensson, Jakob Udesen, and Jane Webb
}

\author{
(6 Banks are not only going to compete with each other") \\ and fintech startups. We're probably also going to have \\ to compete with Amazon, Google, and Apple. Maybe \\ there's going to come a time when all the former rivals \\ will come together.
}

Investment Manager of a Swedish Venture Capitalist Firm (Interviewed for this study)

\begin{abstract}
Financial ecosystems are transforming around new financial technology, or "fintech". As such ecosystems transform, the basis for being seen as legitimate also changes for all actors. Thus, alliances between actors within financial ecosystems are increasingly formed to help gain, maintain, and repair organizational legitimacy. From interviews with fintech startups in Sweden and with venture capitalist firms investing in fintech startups in Sweden, we explore the intertwined quests for organizational legitimacy in a transforming financial ecosystem. As Swedish fintech startups seek to establish a sense of their legitimacy, simultaneously incumbents seek to maintain and repair their organizational legitimacy. Adopting a legitimacy-based view of strategic alliances, we set out the aspects of organizational legitimacy that incumbents and fintech startups look for in a potential partner and how these aspects meet the legitimacy needs of each partner. We argue that alliances further enhance the organizational legitimacy of both fintech startups and incumbents.
\end{abstract}

\section{Introduction}

Recently the surge in new financial technology fintech - has come under increasing attention. Some paint fintech startups as disruptive forces about to revolutionize financial services with major improvements in efficiency, customer centeredness, and informedness (Gomber et al., 2018). Others see this as fintech 3.0 , an era where an increased number of actors provide financial services and develop technology faster (Arner et al., 2016). Various understandings of the current fintech trends are twinned with ambiguity over just what the term fintech actually covers (Gromek, 2018). A straightforward definition of fintech is "companies... that combine financial services with modern, innovative technologies..., offer[ing] Internet-based and application-oriented products" (Dorfleitner et al., 2017). Offerings of fintech startups relate to a broad range of categories, but particularly to automated wealth management, customized insurance, peer-to- peer lending, new payment solutions, crowdfunding, and the trading of stocks (Lee \& Shin, 2018).

The financial ecosystem that fintech startups are helping transform also includes technology developers; government agencies and regulators; financial customers (both private and corporate customers); and traditional financial institutions (incumbents) (Lee \& Shin, 2018). Fintech startups need to take many of these actors into account when developing their services (CB Insights, 2018; Lee \& Shin, 2018). However, they confront a "liability of newness" (Stinchcombe, 1965) while struggling for visibility, influence, and legitimacy in a competitive market. As Payette (2014) details, legitimacy is particularly vital to the growth and survival of technology startups and yet managers often resort to improvising legitimacy-building tactics. Unquestionably, fintech startups engage in other challenges related to commercialization at the same time as legitimacy-building, such as raising awareness among 


\section{Alliances in Financial Ecosystems: A Source of Organizational Legitimacy for Fintech Startups and Incumbents Christopher Svensson, Jakob Udesen, and Jane Webb}

other actors in the financial ecosystem about the potential of new technologies; ensuring that products comply with relevant legislation such as the handling of personal data; and integrating products to cumbersome legacy systems. Here, we focus on how the need for organizational legitimacy of fintech startups relates to the organizational legitimacy needs of incumbents. Understanding how this dynamic may influence commercialization is vital for fintech startups.

We argue in this article that, as financial ecosystems transform, so too does the basis for being perceived as a legitimate actor. Drawing on an interview study, we provide a snapshot of experiences of Swedish fintech startups. We explore the relationship between attempts by fintech startups to establish a sense of their legitimacy and simultaneous attempts by incumbents to maintain and repair organizational legitimacy. Adopting a legitimacy-based view of strategic alliances, we set out the aspects of organizational legitimacy that incumbents and fintech startups look for in a potential partner and how these aspects meet the legitimacy needs of each partner. We argue that alliances further enhance the organizational legitimacy of both fintech startups and incumbents. We call for more research into how ecosystems transformed by technology entrepreneurship involve actors in intertwined quests for organizational legitimacy, and what this means for the commercialization of new technologies.

\section{A Relational Perspective on Technology Ecosystems}

Technological innovation and business model changes are reshaping entire industries (Giones \& Brem, 2017; Kumaraswamy et al., 2018). Such networks of interdependent firms are commonly labelled as business ecosystems (Iansiti \& Levien, 2004). With respect to fintech ecosystems, Lee and Shin (2018) conceptualize an ecosystem as an affiliation, where traditional industry boundaries have broken down, leading to interdependence and symbiotic relationships (Adner, 2017). With this starting point, innovation is understood as radically reconfiguring relationships between ecosystem members, leading to a need to consider how changes in ecosystems affect relationships between a variety of different actors. Understanding the impact of innovation on the relational interdependencies across ecosystems becomes necessary (Adner \& Kapoor, 2010; Dougherty, 2017; Sandström et al., 2014).

Such a relational approach helps reveal the dynamics between firms defending their position in an existing market and those attempting to disrupt it (Kumaraswamy et al., 2018). New ventures often have a relational dependency on incumbents, needing to access complementary resources from incumbents, but ecosystems are, of course, characterized by many differently motivated actors who respond differently to changes (Kumaraswamy et al., 2018). This means that introducing innovation is about "multilateral negotiations with multiple stakeholders that have potentially diverging preferences" (Sandström et al., 2014). We can understand disruption to industries as processual, rather than outcome-based, and as depending "on how the innovation is framed and experienced by the multiple actors involved at different times during the innovation's journey" (Kumaraswamy et al., 2018).

Felländer, Siri, and Teigland (2018) describe a phase in the Swedish financial ecosystem of innovation struggle (from 2007-2008 to mid-2016) and today's phase of partnership and client focus. They argue that there will likely be a new phase of positioning from 2020 driven by technology, in contrast to the earlier consumerdriven and regulations-driven phases. The future phase will be characterized by "a more networked structure with partnerships with fintech actors, while the client databases will be open and secure, enabling the co-creation of services" (Felländer et al., 2018). Moving towards such an era in the finance industry entails changing relationships between incumbents and fintech startups. Exploring how organizations can harness relationships to build sustained competitive advantage becomes important (Dyer \& Singh, 1998).

When considering interdependencies in an ecosystem, the complexity of converging and diverging interests cannot be underestimated. It is vital to understand that there are both "competitive and collaborative dynamics in fintech innovation" (Lee \& Shin, 2018). This means, for example, that fintech startups are less collaborative with incumbents when regulation is favourable for a startup to establish their business (Lee \& Shin, 2018). Even in acquisitions seen as a complementary process, where incumbents want to acquire the assets of a startup and a startup wants to be acquired in order to leverage an incumbent's capabilities, acquisition integration requires careful planning and execution (Carbone, 2011). Within the financial ecosystem, incumbents invest in fintech in a number of ways in addition to the straight route to acquiring or buying fintech (Lee \& Shin, 2018). In this article, we take the view that incumbents cannot take for granted that startups want to be acquired. 


\section{Alliances in Financial Ecosystems: A Source of Organizational Legitimacy for Fintech Startups and Incumbents Christopher Svensson, Jakob Udesen, and Jane Webb}

\section{Forms of Organizational Legitimacy}

This article is about how transformation in ecosystems around technology entrepreneurship changes the basis for being seen as a legitimate actor. Organizational legitimacy is "a generalized perception or assumption that the actions of an entity are desirable, proper, or appropriate within some socially constructed system of norms, values, beliefs, and definitions" (Suchman, 1995). It is "a reaction of observers to the organization as they see it" (Suchman, 1995). While legitimacy is often seen as an "asset", an organization is subject to an ongoing assessment by others of its legitimacy (Bitektine \& Haack, 2015). Suchman (1995) distinguishes between an organization operating in an appropriate manner and being appropriate, as well as whether legitimacy is considered on an episodic or continual basis.

Suchman (1995) identifies three forms of legitimacy pragmatic, moral, and cognitive - that each rest on a different behavioural dynamic. Pragmatic legitimacy is based on the self-interest of an organization's most immediate audience. Moral legitimacy hinges on the normative approval by an audience of an organization's actions and the extent to which the organization is perceived as "doing the right thing". This is about wider societal welfare rather than narrow self-interest. Both pragmatic and moral legitimacy are about discursive evaluation, where cost-benefit appraisals and ethical judgements are carried out through explicit public discussion. Cognitive legitimacy arises when an audience stops evaluating an organization and instead accepts it as necessary. Table 1 summarizes how Suchman (1995) conceptualizes organizational legitimacy. We use this as the first part of our analytical framework.

These forms of organizational legitimacy are in play both when pursuing continuity and when pursuing credibility, as well as when seeking active support and when seeking passive support from audiences. Continuity is about how an audience acts towards an organization, supporting the organization through their everyday actions and allowing the organization to persist. Credibility relates to how an audience understands an organization, considering an organization as worthier, more meaningful, more predictable, and

Table 1. Forms of organizational legitimacy set out by Suchman (1995)

\begin{tabular}{lll}
\hline Form of Legitimacy & Description \\
\hline Pragmatic & Exchange & An audience supports an organization's actions because they benefit from them. \\
\hline & Influence & An audience believes that an organization is responsive to their larger interests. \\
\hline Dispositional & $\begin{array}{l}\text { An audience associates an organization with particular attributes, such as being } \\
\text { trustworthy. }\end{array}$ \\
\hline Consequential & $\begin{array}{l}\text { An audience positively evaluates the generated output or accomplishments of the } \\
\text { organization. }\end{array}$ \\
\hline Procedural & $\begin{array}{l}\text { An organization complies with socially formed and accepted techniques, } \\
\text { procedures, and methodologies. }\end{array}$ \\
\hline Structural & $\begin{array}{l}\text { An organization has in place socially accepted structures that indicate a capacity to } \\
\text { perform specific types of work. }\end{array}$ \\
\hline Personal & $\begin{array}{l}\text { An audience associates an organization with charismatic individuals. } \\
\text { Comprehensibility }\end{array}$ & $\begin{array}{l}\text { An organization fits with available cultural models that provide plausible } \\
\text { explanations for the organization and its endeavours. }\end{array}$ \\
\hline Taken-for- & $\begin{array}{l}\text { An audience considers an organization as irreplaceable - for it not to exist would } \\
\text { be unthinkable. }\end{array}$ \\
\hline
\end{tabular}




\section{Alliances in Financial Ecosystems: A Source of Organizational Legitimacy for Fintech Startups and Incumbents Christopher Svensson, Jakob Udesen, and Jane Webb}

more trustworthy (Suchman, 1995). Ensuring continuity is perhaps of greatest importance to an incumbent, whereas gaining credibility is perhaps more important for startups. Both pursuing continuity and pursuing credibility are parts of whether an organization is assessed as legitimate by audiences.

\section{Strategic Alliances as a Source of Organizational Legitimacy}

There are various internal actions that companies can take to gain, maintain, and repair organizational legitimacy, such as employing experienced leaders and managers with previous knowledge from related fields or locating the company in proximity to a relevant talent pool and an industrial cluster (Rao et al., 2008). Another way that organizations can attempt to gain, maintain or repair organizational legitimacy is to engage in strategic alliances. A strategic alliance is an inter-organizational cooperation that enables the building of competitive advantages. Given that engaging in alliances is often integral to technology startups achieving competitive advantage (Dutta \& Hora, 2017), being perceived as an attractive partner is an important part of growing a startup. Such alliances provide, for example, customer knowledge and distribution channels (Aarikka-Stenroos \& Sandberg, 2012). However, alli- ances can also serve an important legitimating function for organizations and act as a means to an economic or competitive end (Dacin et al., 2007). The legitimating role of strategic alliances is itself a source of competitive advantage (Dacin et al., 2007), helping firms gain more from their innovation (Rao et al., 2008).

Table 2 summarizes the five legitimacy needs that Dacin, Oliver, and Roy (2007) set out as motivations for organizations to consider strategic alliances. We use this as the second part of our analytical framework. Partner selection for an alliance is driven by a variety of factors relevant to each organization's objectives that assess whether an alliance with a potential partner will meet legitimacy needs at the same time as a wider set of objectives (Dacin et al., 2007). For technology startups, organizational legitimacy and legitimacy for a product go hand in hand in commercialization processes, given that the firm and the digital technology are often indistinguishable for digital entrepreneurs (Ingram Bogusz et al., 2018). Technology startups, like any startups, have to balance conforming to expectations within an industry with being distinct (Navis \& Glynn, 2011). How an alliance could function to help a startup achieve "legitimate distinctiveness" - being similar enough and distinct enough - is something startups must consider. Incumbents can consider how an alliance could help

Table 2. Legitimacy needs and functions of strategic alliances set out by Dacin, Oliver, and Roy (2007)

\section{Legitimacy Need}

Market

The need for endorsement and receptiveness by government, suppliers, or customers; often faced by new firms
Legitimating Function of Alliance

Establishes or maintains rights to operate in a specific market with government, suppliers, or customers

Draws in prospective partners by demonstrated collaborative capabilities
Relational

The need to be perceived as an attractive alliance partner in an environment of intense competition for partners

\section{Social}

The need to be seen as socially responsible by stakeholders who closely monitor compliance with rules and expectations
The need for a new business activity to be endorsed internally
Enhances legitimacy as socially responsible with government agencies, local communities, public interest groups, or customers

Legitimates business activities in the eyes of corporate executives, boards, venture capitalist firms, and shareholders

Legitimates the alliance form while also helping meet other legitimacy needs
Alliance

The need for alliances to be endorsed, particularly in industries without a history of using alliances 


\section{Alliances in Financial Ecosystems: A Source of Organizational Legitimacy for Fintech Startups and Incumbents Christopher Svensson, Jakob Udesen, and Jane Webb}

them maintain organizational legitimacy and gain competitive advantage in an ecosystem transforming around new technologies.

\section{Methods}

\section{Research context}

This article draws on data from an explorative study about the growth of fintech startups in Sweden. The Nordic fintech sector is growing rapidly with annual investments of $€ 163$ million ( $\$ 250$ million CAD) during 2016, doubling the amount from 2014 (Jonsdottir et al., 2017). Sweden is currently the second largest fintech community in Europe. Swedish consumers are known to be early adopters of new technologies, with Sweden leading for over a decade in the uptake of online banking (Björn, 2018). In the past, the banks have worked together to introduce two successful fintech services: Swish, a payments service for transfer between private customers launched in 2012, and BankID, a digital identification service launched online in 2003 and on mobile in 2010. The launch of Swish occurred during an era that Felländer and co-authors (2018) see as the first phase of fintech in Sweden, when the banks awakened to the success of fintech startups such as Klarna and iZettle and cooperated with each other to introduce new technology. We carried out the research in the current phase of partnership and client focus, that in the next few years will likely give way to a phase of positioning, driven by technology and when client databases will be more open (Felländer et al., 2018).

\section{Data collection}

The study began during a conversation between two of the authors and the founders of a Swedish fintech startup. During that conversation, the founders repeatedly returned to the uncertainty they were facing about how to approach markets outside Sweden. Based on this, we chose to explore the internationalization experiences of Swedish fintech startups, focusing on partnership strategies. We interviewed representatives from fintech startups, as well as venture capitalist firms (VCs), because VCs are often involved at an early stage in the particularly capital-intensive area of fintech (Jonsdottir et al., 2017).

Two of the authors jointly carried out 19 interviews over four weeks (February to March 2018). Fifteen of these interviews were with fintech startups in Sweden, and four were with investors introduced to us by the fintech startups. The interviewees from startups were business developers, founders, or CEOs with strategic responsibility for the long-term vision of the startup. We identi- fied the startups by using the Nordic Tech List (2018). These startups were "new ventures developing software based financial services" (Dorfleitner et al., 2017) and: i) had received at least $€ 1 \mathrm{M}(\sim \$ 1.5 \mathrm{M}$ CAD) in funding; ii) had a corporate website in at least two languages; and iii) had been founded in Sweden. According to Lee and Shin's (2018) typology of the business models of fintech startups, the 15 interviewed fintech startups included: capital market (1), insurance (1), crowdfunding (1), wealth management (3) and payment (7). The remaining two fintech startups - one with software enabling the use of artificial intelligence, another with a product enabling authentication on a smartphone - combined elements of a fintech startup with a technology developer. We also interviewed four investors that were: i) based in Sweden; ii) investing in fintech startups, and iii) working with portfolio companies that had expanded outside Sweden. Two of the investors were from bank-owned VCs, one was from a bank investing in fintech startups, and one was from a general VC.

We developed the interview guide to invite reflections from each interviewee about the experience of initial internationalization efforts by Swedish fintech startups. In line with the explorative research design, the interviews were semi-structured to allow an interviewee to elaborate on aspects particularly important to them. The interviews each lasted 40-60 minutes and were recorded. One researcher asked the questions, while the other took notes. Immediately after each interview, the two researchers wrote up an interview summary. Later they transcribed all interviews.

\section{Data analysis}

Across the interviews were comments about establishing trust with other actors in the financial ecosystem and the need to work through incumbents, both in Sweden and in new markets. To zoom in on the interplay of organizational legitimacy of incumbents and fintech startups, we mapped how different actors in the financial ecosystem assessed a fintech startup, and how different actors in the financial ecosystem assessed an incumbent. Using Suchman's (1995) definition of organizational legitimacy, by audience we looked at: i) the norms, values, and beliefs and ii) desirable, proper, or appropriate actions. Our research design for understanding the experiences of fintech startups gave particular insights into how fintech startups assess the legitimacy of incumbents and how incumbents assess the legitimacy of fintech startups.

In the next section, we present interview snippets about why incumbents are interested in partnering 


\section{Alliances in Financial Ecosystems: A Source of Organizational Legitimacy for Fintech Startups and Incumbents Christopher Svensson, Jakob Udesen, and Jane Webb}

with fintech startups and why fintech startups are interested in partnering with incumbents. We emphasize the main points of each snippet in bold. The snippets illustrate the legitimacy needs of incumbents and fintech startups.

We then synthesize our analysis into a model of the desirable actions and attributes that fintech startups and incumbents look for in a partner. Next, we illustrate how fintech startups signaled trustworthiness to incumbents before outlining what we understand as the implications for fintech startups stemming from our findings about organizational legitimacy in financial ecosystems.

\section{A Wave of Innovation Transforming the Financial Ecosystem}

Why were established actors interested in partnering with fintech startups? What were the general legitimacy needs of incumbents? Interviewees spoke about how banks in Sweden are realizing that they need to transform their working processes. They spoke of a "wave of innovation" and of the change to the finance industry since new regulations (i.e., the EU's Payment Services Directive, or PSD2) had come into force. All of this challenged the ways that banks were used to working and how they maintained customer loyalty. This new picture of the financial ecosystem meant that banks were considering how to work with other actors. It was clear, however, that banks hoped to partner with fintech startups on their terms - by owning a controlling share of fintech startups.

A representative of a bank-owned VC said this about the impact of changing regulations:

"I believe that the traditional banks will encounter more and more challenges related to their way of doing business. They will be attacked from many different angles." (Investor D)

Such challenges to the banks' ways of working had had a positive impact on a wealth management startup, according to its CEO:

"Our sales process is becoming easier now as the banks are realizing that the regulations are changing. The banks have a big spending budget and their demand for innovation is increasing as they see that there will be new competitors as a consequence of PSD2... If you are a bank and I am PSD2-certified, then I can force you to give me your data." (Fintech Startup O)
The investment manager from a VC working specifically with fintech partnerships went further. He pointed to the potential of even greater cooperation within the financial ecosystem to block non-financial actors establishing themselves:

\section{"We need to understand that the wave of innova- tion that is coming means that banks are not only going to compete with each other and fintech startups. We're probably also going to have to compete with Amazon, Google, Apple, etc. Maybe there's going to come a time when all the former rivals will come together and say 'Oh my God. We have to do this or we're going to die."' (In- vestor B)}

There seemed to be two main reasons that incumbents wanted to partner with fintech startups, according to the interviewees. The first was about retaining legitimacy in the eyes of their customers:

"The banks care about their customers' long-term view of the bank. Five years from now, they want their customers to still look at them as legitimate service providers. They understand that they need to add new functionality." (Fintech Startup O)

The second explanation for why incumbents wanted to partner with startups was about moving to a more open banking system:
"An IT executive at [Swedish Bank] put it really well. He said that, up to now, they've tried to make their systems as closed and secure as pos- sible. Now they're facing demands to open up these systems and share them with everyone else. Those are two completely different mindsets. It's really clear that the banks are struggling to trans- ition from a closed community to an environ- ment where everything is shared." (Fintech Startup K)

Despite the interest in partnering with fintech startups, the banks expected to have control of fintech startups:

\section{"The banks are after innovation, but they also want revenue share and ownership in the fintech startup." (Fintech Startup K)}

One of the motivations of banks for such control may have been a wish to act cautiously due to their standing in the financial ecosystem and their fear of adverse customer impact: 


\section{Alliances in Financial Ecosystems: A Source of Organizational Legitimacy for Fintech Startups and Incumbents Christopher Svensson, Jakob Udesen, and Jane Webb}

\begin{abstract}
"Banks are in a situation where they're almost considered as government bodies. They simply cannot make decisions that could affect customers negatively." (Fintech Startup O)
\end{abstract}

From these interview snippets, we see that incumbents had legitimacy needs in terms of being seen as able to keep apace with the opening up of banking brought about by changing regulations and by fintech innovation. Their established status put them in need of maintaining legitimacy, rather than gaining legitimacy. This could be classified primarily as a need for market legitimacy, but with clear links also to investment legitimacy and to alliance legitimacy (Dacin et al., 2007). Through the right partner, an incumbent could validate the alliance form, as well as signal to a variety of stakeholders that the company had an intention to expand and improve current services to customers.

\section{A Long Journey for Approval}

Some of the interviewees represented a fintech startup where their business model was dependent on other actors within the financial ecosystem for access to infrastructure such as payment systems or authentication systems. For such fintech startups, acquisition and shared ownership were part of commercialization strategies. Beyond this, what were the reasons that fintech startups had for partnering with established actors? What were the general legitimacy needs of fintech startups? Interviewees emphasized how fintech startups were generally dependent on the banks, because the banks had standing akin to being government bodies. Banks had knowledge and expertise that could help fintech startups navigate regulatory frameworks. The banks were able to verify customer need for new services and open doors to partners and customers in new markets.

One manager at a bank investing in fintech, talked about what differentiated fintech startups from other technology-based startups:

"Based on the companies that we've previously invested in, it's always been a given that SaaS startups [Software as a Service] are 'born global' right from the start. For fintech companies, it's a different story because there are so many regulatory aspects that need to be considered. Fintech companies have to go through quite a long journey before they have a final product approved by the

Financial Authority." (Investor C)
An investment manager at a VC described why fintech startups depended on the banks:

"Fintech need the banks. They still need the banks because it's the banks that have the banking licenses." (Investor B)

Some interviewees emphasized the support they received to identify barriers to entry in different markets. Commonly, the main expertise that was mentioned as being invaluable to fintech startups was how to make sense of regulations. A senior advisor at a bank-owned VC spoke about how experience working with a number of fintech startups meant that the firm's lawyers were able to offer tailor-made advice:

"As we've navigated the regulatory frameworks for a while, we've learned how to apply them correctly to new products. I can use our lawyers, who have a thorough understanding of the frameworks, to supply knowledge to our portfolio companies." (Investor A)

Providing legal expertise was part of what a partnership with a fintech startup entailed for a bank. One interviewee put it like this:

"That's one huge advantage of collaborating with a bank - they possess a lot of knowledge and an army of lawyers if there was ever any legal complication. Since we have implemented our service in their platform, it's in their interest to help us." (Fintech Startup O)

Beyond complying with all the regulatory and procedural requirements of a bank or of national regulators, the interviewees also emphasized how incumbents provided access to customers both in Sweden and in other markets, and helped verify customer need:

"What helped us there, was that they introduced us to all their customers. We basically got to meet every big bank in the UK through our partner [a Swedish bank]." (Fintech Startup I)

"It's a huge advantage when you're working with such a big bank. They have resources to thoroughly verify the market demand. They would not have accepted us as a partner if they had not verified the need with their customers first. We assume that the incumbents have a good idea of what their customers want." (Fintech Startup O) 


\section{Alliances in Financial Ecosystems: A Source of Organizational Legitimacy for Fintech Startups and Incumbents Christopher Svensson, Jakob Udesen, and Jane Webb}

One interviewee from a payments fintech startup talked about how his company gained access to credit card customers through partnering with a bank:

"Through that partner [a bank], we secured a much cheaper customer acquisition cost. We didn't need to market ourselves to the same extent. We could rely a lot on the alliance with the bank who already had a customer base. They just went out to their customers and told them that we existed." (Fintech Startup I)

From these interview snippets, we see that fintech startups had legitimacy needs in terms of being seen to comply with regulations and to reach customers to validate the product. The status put them in need primarily of gaining market legitimacy (Dacin et al., 2007) as they tackled the "liability of newness" (Stinchcombe, 1965). There were links, too, to social legitimacy and investment legitimacy (Dacin et al., 2007), as fintech startups sought to be seen as compliant by regulators and to signal to investors the worth of their business through entering into a strategic alliance with an experienced partner.

\section{Intertwined Quests for Organizational Legitimacy}

The interviews provide insight into how the motivations for partnerships between incumbents and fintech startups are underpinned by legitimacy needs. From the primary need of market legitimacy for fintech startups and incumbents, it becomes clearer what makes each actor an attractive partner for the other. Figure 1 illustrates the complementary nature of the quests for organizational legitimacy that fintech startups and incumbents engage in. The figure depicts the desired actions and attributes associated with organizational legitimacy central in alliances between fintech startups and incumbents. These are the criteria for partner selection and show how the legitimacy needs of each actor relate. Joint accomplishments from the partnership enhance the organizational legitimacy for both partners with a variety of stakeholders, helping to meet a package of legitimacy needs of each partner. Below, we summarize the actions and attributes using Suchman's (1995) conceptualization of forms of organizational legitimacy. A key element of this representation is that the nature of gaining, maintaining, or repairing organizational

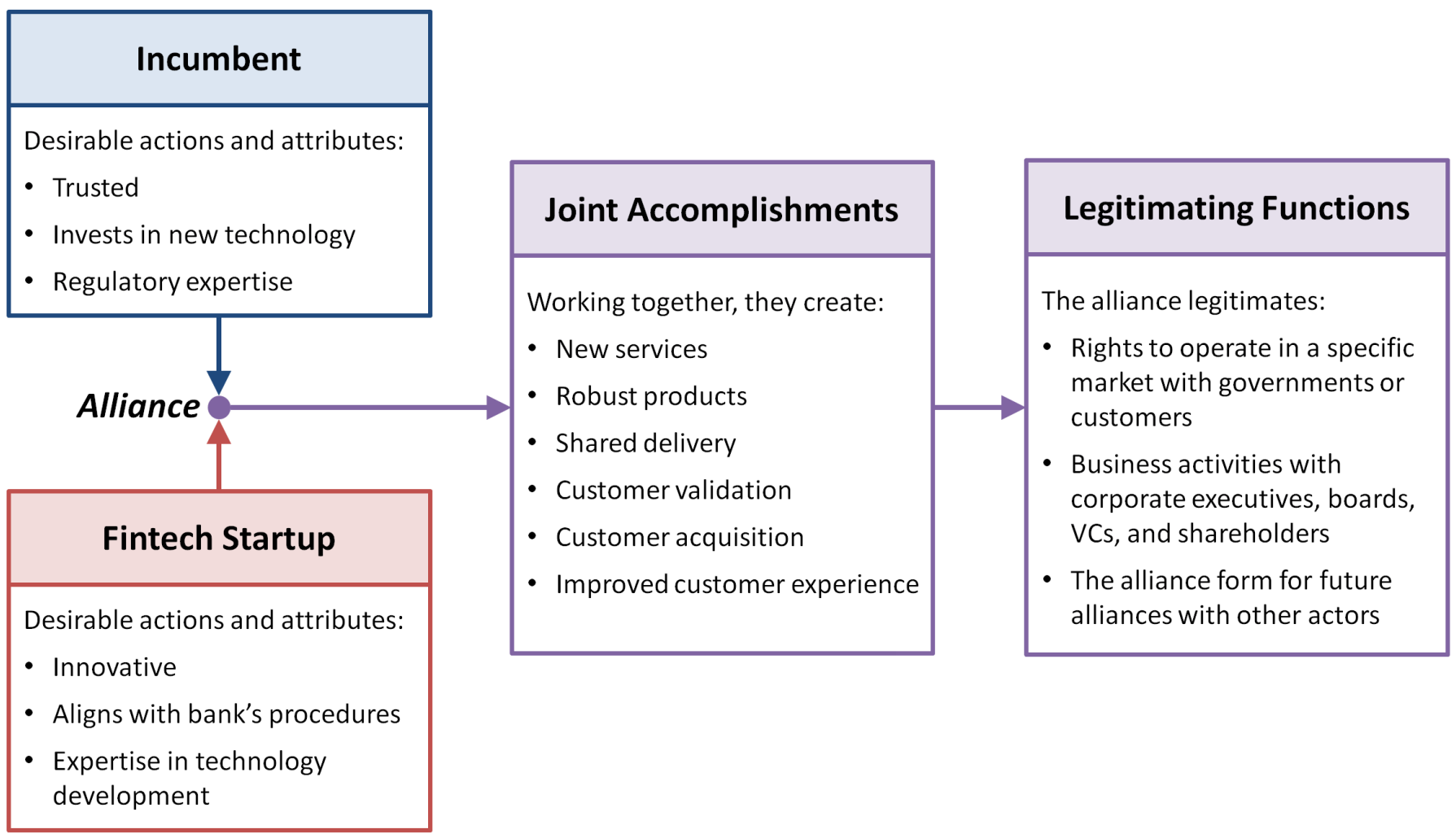

Figure 1. Legitimating functions of alliances between a fintech startup and an incumbent to meet organizational legitimacy needs of each partner 


\section{Alliances in Financial Ecosystems: A Source of Organizational Legitimacy for Fintech Startups and Incumbents Christopher Svensson, Jakob Udesen, and Jane Webb}

legitimacy, as Suchman (1995) describes, means that organizational legitimacy is not an "asset" that arises from a strategic alliance, but is subject to the ongoing assessment of an actor by various audiences.

\section{Dispositional legitimacy and taken-for-grantedness}

Incumbents associate a legitimate fintech startup with being innovative and having an ability to translate user input into new functionality. An incumbent's organizational legitimacy is enhanced through new or improved services and the connection to improved customer experience. For an incumbent to be perceived as legitimate by a fintech startup, it would have achieved a level of taken-for-grantedness that means it is trusted by customers. This shows a relationship between pursuing credibility (a fintech startup) and pursuing continuity (an incumbent). An alliance can help meet these legitimacy needs. Rather than considering that the legitimacy of an incumbent is "extended" to a startup as if an asset, it is more the case, we argue, that both partners in alliances can benefit from the positive assessment by others of the joint accomplishments with their partner.

\section{Influence legitimacy}

Both fintech startups and incumbents expect each other to be responsive to their larger interests. Fintech startups expect a legitimate incumbent to recognize the transforming financial ecosystem and a need to improve their services or to add new services. They expect an incumbent to respect a fintech startup's capacity to apply advanced technology that transforms financial services. Incumbents expect a legitimate fintech startup to be willing to align with their policies, procedures, and demands and respect an incumbent as an expert in following accepted rules and norms. This points to a shared understanding of the financial ecosystem, where both incumbents and fintech startups need to work together because their organizational legitimacy is based on different actions and expertise. We can understand here that there is not a straight case of fintech startups either fitting to the processes of incumbents or of disrupting processes. Instead, there is a process in between the two, given that both fintech startups and incumbents benefit from fitting in with existing processes and with changes to processes. It is perhaps through alliances that fintech startups and incumbents get the chance to explore a midway between fit-to-process and disruption.

\section{Exchange legitimacy}

Both fintech startups and incumbents supported particular actions of the partner as ones that they would benefit from. This meant that the technology development processes of a fintech startup would benefit an incumbent, while the expertise in complying with regulations would benefit a fintech startup. Each partner expected that the other would share such competencies with them through the partnership. This would be of direct benefit in carrying out business activities.

\section{Consequential legitimacy}

The joint accomplishments from partnering provided a consequential legitimacy for both actors in the eyes of private and corporate customers, investors, shareholders, regulators, and employees, as well as other fintech startups and incumbents. By receiving assistance from an incumbent in complying with regulations, the fintech startup gained social legitimacy from government agencies and regulators. For a fintech startup, building a track record of successful partnerships was a key factor connected to organizational legitimacy that was of interest to potential partners. This helped meet a relational legitimacy need. As one interviewee said:

"This actor has been faster in their decisions, compared to our first partner. We were surprised that they were so much faster. We have our first alliance to thank for that - the new partner considered that alliance an assurance." (Fintech Startup O)

For incumbents, adding a new service that helped with customer retention and customer acquisition was of benefit in the eyes of shareholders and employees. It both met a social and an investment need for legitimacy. As one interviewee said:

"We also have responsibility with our investments to help employees feel that we are moving forward, that we're more agile, and that we're working more closely with startups." (Investor C)

\section{Trustworthiness Signals by Fintech Startups}

Despite the needs for organizational legitimacy of both incumbents and fintech startups, interviewees from fintech startups spoke of the considerable challenges they had faced in navigating the financial ecosystem. In the accounts during the interviews, the interviewees drew on the perceived advantages of fintech startups speed, technical know-how, streamlined decision-making, produce development processes - to frame what they had to offer as new actors in the financial ecosystem. The interviewees talked about the steps they took to signal trustworthiness to potential partners, such as hiring sales and marketing executives as part of estab- 


\section{Alliances in Financial Ecosystems: A Source of Organizational Legitimacy for Fintech Startups and Incumbents Christopher Svensson, Jakob Udesen, and Jane Webb}

lishing a local office in potential markets, partnering with consultancy firms when approaching banks in a new market, appointing board members with a strong network, and the importance of emphasizing a track record.

Time and again, interviewees emphasized the speed under which fintech startups are used to working. The CEO at a payments fintech startup referred to the advantage that fintech startups have over other actors in the financial ecosystem:

"We need to move as fast as possible, because that is the only advantage that we have. The big companies have much more money than us, but we can make faster decisions." (Fintech Startup I)

The same interviewee went on to say this about banks:

"They have a different perspective on what a fast process is. For the incumbents one year is fast. No exaggeration. But, in our case, one year is a whole capital cycle. It's a matter of survival. We have to maintain the intensity in the relationship and be persistent." (Fintech Startup I)

The different pace of the banks presented a way for the fintech startups to distinguish themselves. For the CEO of a startup developing a service that enables authentication through a smartphone, the speed of delivering their installation to a bank appeared to be a badge of honour:

"The bank had never heard of an integration that was so fast. A proof of concept was installed and done in seven weeks - that was a record." (Fintech Startup F)

In terms of how they had strengthened the organizational profile, a co-founder from a startup with an invoicing service, talked about how, when targeting companies using enterprise resource planning (ERP) systems as potential customers, the number of employees was an important signal:

"When we launched our service, many potential customers asked us why they should choose us instead of our competitors. No one knew who we were. We had to establish trust in the service and in the company. Now we're over 200 employees so potential customers see that there is some power behind the company. That signals trustworthiness to a certain extent. If our customers are going to use our service, they need to trust us. It is vital for us and trust takes time to establish." (Fintech Startup G)

Another interviewee emphasized that hiring sales executives familiar with particular local markets was a way to be taken more seriously:

"I believe that, if you are a bank, you ask yourself why you should work with our company. We don't even have a local sales representative. But if they say: ' $S * * t$, they've hired [Name]. They're really going for it - this is serious.' It sends a signal." (Fintech Startup C)

Others signaled experience in the finance industry and gained influence by appointing particular board members:

"I would recommend to other fintech startups that they find experienced board members. This is not the first company I have built. Not everyone has access to the kind of network that we have." (Fintech Startup E)

\section{Implications for Fintech Startups}

We argue that, to achieve clarity about how and why to act in particular ways, an actor must assess the legitimacy needs of other actors in a transforming ecosystem and evaluate the strength of their own organization's organizational legitimacy. This helps an actor position themselves as an attractive partner for possible strategic alliances that can help actors gain, maintain, or repair organizational legitimacy. Thus, there are ongoing simultaneous quests for legitimacy, given legitimation is a social process where all actors within the financial ecosystem are assessing each other and being assessed by other stakeholders. For fintech startups, organizational legitimacy and legitimacy for a particular product go hand in hand. The accomplishments valued by a range of stakeholders mean that an alliance helps gain legitimacy for both the organization and the product. For a startup, building legitimacy is a part of the necessary identity formation that creates competitive advantage (Lounsbury \& Glynn, 2001).

Although, in 1995, Suchman described banks as belonging to an archetype of permanent, structurally legitimate organizations of good character, in 2019, a changing financial ecosystem means that banks are no longer perceived the same way. However, even though the status of banks was changing, fintech startups retained 


\section{Alliances in Financial Ecosystems: A Source of Organizational Legitimacy for Fintech Startups and Incumbents Christopher Svensson, Jakob Udesen, and Jane Webb}

their hopes that they could piggyback on the established status of incumbents. Given that tackling the "liability of newness" (Stinchcombe, 1965) is about mobilizing affirmative commitments, fintech startups must prove that they have "value". Fintech startups accentuated their perceived advantages in order to be attractive to incumbents. It is unclear from the interviews who dictates the terms in the financial ecosystem in Sweden - is it more a case of fintech startups gaining legitimacy by conforming to the environment controlled by incumbents or is it more a case of fintech startups manipulating the environment? This could be a crucial question for each fintech startup in order to be seen as a vital actor within the financial ecosystem. There may be a midway between confirming and manipulating, between fit-to-process and disruption, that is mutually beneficial to both fintech startups and incumbents.

Along with putting effort into emphasizing that a fintech startup is falling in line with compliance requirements, each fintech startup needs to shift the conversation, too, about just what is different about their organization and services. This could mean engaging in creating a shared vision of future changes in technology with other fintech startups and setting an agenda on this, as Bailetti (2012) suggests. This helps build legitimacy for a new way of relating between actors within the transforming financial ecosystem. However, a manager of a fintech startup no doubt also gains legitimacy for their organization by demonstrating awareness of socially accepted procedures and structures. We suggest that playing up the legitimate distinctiveness of a fintech startup and how this distinctiveness complements the legitimacy of another actor is crucial to responding to the intertwined quests for organizational legitimacy within financial ecosystems.

\section{Conclusion}

From interviews with representatives from fintech startups and VCs, we have explored the intertwined quests of fintech startups and incumbents related to their needs to gain, maintain, and repair organizational legitimacy. We have argued that, by partnering with each other, fintech startups and incumbents can meet organizational legitimacy needs and further enhance organizational legitimacy through the joint accomplishments arising from alliances. The legitimating functions of strategic alliances are considered as building competitive advantage for fintech startups and incumbents in a transforming financial ecosystem. Alliances primarily help establish or maintain rights to operate in a specific market with governments or customers; but, they can also legitimate business activities in the eyes of corporate executives, boards, VCs, and shareholders. While meeting these legitimacy needs, an alliance may also help legitimate the alliance form as a part of strategy for future cooperation with other actors in the financial ecosystem.

This article brings to the fore the necessity - for both fintech startups and incumbents - of managing organizational legitimacy and considering it as a vital part of strategy. Considering the interplay of legitimacy needs across actors in a financial ecosystem makes clearer what managers of a fintech startup can emphasize when seeking to position themselves as attractive partners. To meet the expectations of incumbents, managers from fintech startups emphasize innovative services with sound business models that add value to an incumbent's platform. They are prepared to comply with the incumbent's policies and procedures. In turn, the managers of fintech startups seek out incumbents who are trusted by customers, who are investing in new technology, and who are willing to support the fintech startup in navigating regulatory frameworks. Together, an incumbent and a fintech startup may achieve a midway approach that harnesses each other's expertise to achieve competitive advantage in the financial ecosystem transforming around new technology.

This article provides but a snapshot of the current moment from the perspective of Swedish fintech startups with regards to relationships between fintech startups and incumbents. It offers a starting point for research on intertwined quests for legitimacy in financial ecosystems. A follow-up to this explorative article would be to systematically map the legitimacy needs of all organizational actors in a financial ecosystem and how this impacts technology commercialization, performance, and strategy. Investigating the perceptions of both corporate and private customers about the legitimacy of financial actors could reveal pressing legitimacy challenges that make necessary strategic alliances. This article also opens up opportunities for exploring intertwined quests for legitimacy in other ecosystems transforming due to technology entrepreneurship. In addition, researchers could study how organizational legitimacy needs interact with other business needs to influence strategies adopted by technology startups and by incumbents, especially in relation to when to choose acquisition and when to choose alliance. 


\section{Alliances in Financial Ecosystems: A Source of Organizational Legitimacy for Fintech Startups and Incumbents Christopher Svensson, Jakob Udesen, and Jane Webb}

\section{Acknowledgements}

This article draws on a research project carried out from January to May 2018 to conclude Master of Science programs at Chalmers University of Technology, Sweden. The report Actions to Gain Legitimacy in the Swedish Financial Sector: A Study of Swedish Fintech Startups by Christopher Svensson and Jakob Udesen is available at: tinyurl.com/ya8zhzrv

\section{About the Authors}

Christopher Svensson is a Business Developer and fintech enthusiast working at Minna Technologies, a fintech startup in Sweden. He has a Master's degree in Mechanical Engineering, with a focus on Quality and Operations Management, from Chalmers University of Technology, Sweden. He has also studied Economics at the Gothenburg School of Business, Economics and Law, Sweden. His multidisciplinary background within Technology Management and Economics has shaped Christopher's particular interest in how technology startups transform and disrupt industries.

Jakob Udesen is an Associate Business Developer working at Tetra Pak. He holds a Master's degree in Industrial Engineering, with a focus on the Management and Economics of Innovation, from Chalmers University of Technology, Sweden. A part of his Master's level studies was carried out at the Lisbon School of Economics and Management, Portugal. Jakob has a strong interest in how to manage innovation processes to ensure the best financial outcomes, and he has a deep understanding of agile processes as well as classic management approaches.

Jane Webb is a $\mathrm{PhD}$ candidate in Innovation Management and Organizational Behavior at Chalmers University of Technology, Sweden. Her doctoral research draws on a two-year ethnographic study of a partnership of 15 organizations testing and demonstrating electric vehicles and related services "live" in a city. Her interest is in how participants in collaborative innovation successfully nurture a web of goals to keep joint work alive. Jane has previous experience in policy, project, and operations management in the public sector, as well as in design research.

\section{References}

Aarikka-Stenroos, L., \& Sandberg, B. 2012. From New-Product Development to Commercialization through Networks. Journal of Business Research, 65(2): 198-206.

https://doi.org/110.1016/j.jbusres.2011.1005.1023

Adner, R. 2017. Ecosystem as Structure: An Actionable Construct for Strategy. Journal of Management, 43(1): 39-58.

https://doi.org/10.1177/0149206316678451

Adner, R., \& Kapoor, R. 2010. Value Creation in Innovation Ecosystems: How the Structure of Technological Interdependence Affects Firm Performance in New Technology Generations. Strategic Management Journal, 31(3): 306-333. https://doi.org/310.1002/smj.1821

Arner, D. W., Barberis, J., \& Buckley, R. P. 2016. 150 Years of Fintech: An Evolutionary Analysis. Jassa, 2016(3): 22-29.

Bailetti, T. 2012. Technology Entrepreneurship: Overview, Definition, and Distinctive Aspects. Technology Innovation Management Review, 2(2): 5-12.

http://doi.org/10.22215/timreview/520

Bitektine, A., \& Haack, P. 2015. The "Macro" and the "Micro" of Legitimacy: Toward a Multilevel Theory of the Legitimacy Process. Academy of Management Review, 40(1): 49-75.

https://doi.org/10.5465/amr.2013.0318

Björn, M. 2018. The Adoption of Online Banking in Sweden. In R. Teigland, S. Siri, A. Larsson, A. Moreno Puertas, \& C. Ingram Bogusz (Eds.), The Rise and Development of FinTech: Accounts of Disruption from Sweden and Beyond. New York: Routledge.

Carbone, P. 2011. Acquisition Integration Models: How Large Companies Successfully Integrate Startups. Technology Innovation Management Review, 1(1): 26-31.

http://doi.org/10.22215/timreview/490

CB Insights. 2018. Fintech Trends to Watch in 2018. New York: CB Insights.

https://www.cbinsights.com/research/report/fintech-trends2018/

Dacin, M. T., Oliver, C., \& Roy, J. P. 2007. The Legitimacy of Strategic Alliances: An Institutional Perspective. Strategic Management Journal, 28(2): 169-187.

https://doi.org/110.1002/smj.1577

Dorfleitner, G., Hornuf, L., Schmitt, M., \& Weber, M. 2017. FinTech in Germany. Cham, Switzerland: Springer.

https://doi.org/10.1007/978-3-319-54666-7

Dougherty, D. 2017. Organizing for Innovation in Complex Innovation Systems. Innovation: Organization \& Management, 19(1): 11-15.

https://doi.org/10.1080/14479338.14472016.11245109

Dutta, D. K., \& Hora, M. 2017. From Invention Success to Commercialization Success: Technology Ventures and the Benefits of Upstream and Downstream Supply-Chain Alliances. Journal of Small Business Management, 55(2): 216-235. https://doi.org/210.1111/jsbm.12334

Dyer, J. H., \& Singh, H. 1998. The Relational View: Cooperative Strategy and Sources of Interorganizational Competitive Advantage. Academy of Management Review, 23(4): 660-679. https://doi.org/610.2307/259056 


\section{Alliances in Financial Ecosystems: A Source of Organizational Legitimacy for Fintech Startups and Incumbents Christopher Svensson, Jakob Udesen, and Jane Webb}

Felländer, A., Siri, S., \& Teigland, R. 2018. The Three Phases of FinTech. In R. Teigland, S. Siri, A. Larsson, A. Moreno Puertas, \& C. Ingram Bogusz (Eds.), The Rise and Development of FinTech: Accounts of Disruption from Sweden and Beyond. New York: Routledge.

Giones, F., \& Brem, A. 2017. From Toys to Tools: The Co-Evolution of Technological and Entrepreneurial Developments in the Drone Industry. Business Horizons, 60(6): 875-884. https://doi.org/810.1016/j.bushor.2017.1008.1001

Gomber, P., Kauffman, R. J., Parker, C., \& Weber, B. W. 2018. On the Fintech Revolution: Interpreting the Forces of Innovation, Disruption, and Transformation in Financial Services. Journal of Management Information Systems, 35(1): 220-265. https://doi.org/210.1080/07421222.07422018.01440766

Gromek, M. 2018. Clarifying the Blurry Lines of FinTech: Opening the Pandora's Box of FinTech Categorization. In R. Teigland, S. Siri, A. Larsson, A. Moreno Puertas, \& C. Ingram Bogusz (Eds.), The Rise and Development of FinTech: Accounts of Disruption from Sweden and Beyond. New York: Routledge.

Iansiti, M., \& Levien, R. 2004. The Keystone Advantage: What the New Dynamics of Business Ecosystems Mean for Strategy, Innovation, and Sustainability. Boston: Harvard Business Press.

Ingram Bogusz, C., Teigland, R., \& Vaast, E. 2018. Designed Entrepreneurial Legitimacy: The Case of a Swedish Crowdfunding Platform. European Journal of Information Systems. https://doi.org/10.1080/0960085X.2018.1534039

Jonsdottir, F., Toivonen, O., Jaatinen, V., Utti, A., \& Lindqvist, R. 2017. FinTech in the Nordics: A Deloitte Review. Deloitte, January 24, 2017. Accessed July 24, 2018. https://www2.deloitte.com/content/dam/Deloitte/se/Documents /financial-services/FinTech_Publikation_A4_WEB_FINAL.PDF

Kumaraswamy, A., Garud, R., \& Ansari, S. S. 2018. Perspectives of Disruptive Innovation. Journal of Management Studies, 55(7): 1025-1042.

https://doi.org/1010.1111/joms.12399

Lee, I., \& Shin, Y. J. 2018. Fintech: Ecosystem, Business Models, Investment Decisions, and Challenges. Business Horizons, 61(1): $35-46$.

https://doi.org/10.1016/j.bushor.2017.1009.1003

Lounsbury, M., \& Glynn, M. A. 2001. Cultural Entrepreneurship: Stories, Legitimacy, and the Acquisition of Resources. Strategic Management Journal, 22(6-7): 545-564. https://doi.org/510.1002/smj.1188
Navis, C., \& Glynn, M. A. 2011. Legitimate Distinctiveness and the Entrepreneurial Identity: Influence on Investor Judgments of New Venture Plausibility. Academy of Management Review, 36(3): 479-499.

https://doi.org/410.5465/amr.2008.0361

Nordic Tech List. 2018. Nordic Tech List. Stockholm: Dagens Industri. Accessed January 18, 2018: http://www.nordictechlist.com

Payette, J. 2014. Resolving Legitimacy Deficits in Technology Startups through Professional Services Practices. Technology Innovation Management Review, 4(6): 22-27. http://doi.org/10.22215/timreview/801

Rao, R. S., Chandy, R. K., \& Prabhu, J. C. 2008. The Fruits of Legitimacy: Why Some New Ventures Gain More from Innovation than Others. Journal of Marketing, 72(4): 58-75. https://doi.org/10.1509/jmkg.1572.1504.1558

Sandström, C., Berglund, H., \& Magnusson, M. 2014. Symmetric Assumptions in the Theory of Disruptive Innovation: Theoretical and Managerial Implications. Creativity and Innovation Management, 23(4): 472-483.

https://doi.org/410.1111/caim.12092

Stinchcombe, A. 1965. Social Structure and Organizations. In J. G. March (Ed.), Handbook of Organizations. Chicago: Rand McNally.

Suchman, M. C. 1995. Managing Legitimacy: Strategic and Institutional Approaches. Academy of Management Review, 20(3): 571-610. https://doi.org/510.2307/258788

Citation: Svensson, C., Udesen, J., \& Webb, J. 2019. Alliances in Financial Ecosystems: A Source of (cc) BY Organizational Legitimacy for Fintech Startups and Incumbents. Technology Innovation Management Review, 9(1): 20-32.

http://doi.org/10.22215/timreview/1209

Keywords: fintech startups, organizational legitimacy, financial ecosystems, strategic alliances, relational perspective 


\section{Academic Affiliations and Funding Acknowledgements}
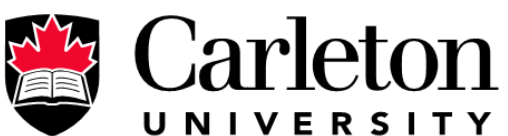

U N I V E R S I T Y

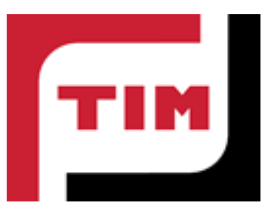

Technology Innovation Management (TIM; timprogram.ca) is an international master's level program at Carleton University in Ottawa, Canada. It leads to a Master of Applied Science (M.A.Sc.) degree, a Master of Engineering (M.Eng.) degree, or a Master of Entrepreneurship (M.Ent.) degree. The objective of this program is to train aspiring entrepreneurs on creating wealth at the early stages of company or opportunity lifecycles.

- The TIM Review is published in association with and receives partial funding from the TIM program. 